\title{
Mandibular reconstruction with autogenous non-vascularised bone graft
}

\author{
Ramat Oyebunmi Braimah ${ }^{1}$, Adebayo Aremu Ibikunle², Umar Abubakar ${ }^{3}$, Abdurrazaq Olanrewaju Taiwo ${ }^{4}$, Muhammed Oboirien ${ }^{5}$, \\ Francis Adewale Adejobi ${ }^{6}$, Terry Godwin Ndubuisi ${ }^{7}$, Siddiq Abubakar ${ }^{8}$
}

1. Department of Dental and Maxillofacial Surgery, Usmanu Danfodio University Teaching Hospital, Sokoto, Nigeria.

Email; robdeji@yahoo.com., bunmibraimah@gmail.com Phone number +234 8035839900

2. Consultant Oral and Maxillofacial Surgeon, Department of Dental and Maxillofacial Surgery, Usmanu Danfodiyo University Teaching Hospital, Sokoto, Nigeria. E-mail: adebayoibikunle@gmail.com, Phone number: +234 8029190888

3. Lecturer/Honourary Consultant Cardio-thoracic surgeon, Cardio-thoracic Surgery unit, Department of Surgery, College of Health Sciences, Usmanu Danfodiyo University/ Usmanu Danfodiyo University Teaching Hospital, Sokoto, Nigeria. E-mail: drzuru@yahoo.com , Phone number: +234 8036012733

4. Senior Lecturer/Honorary Consultant, Department of Surgery/Dental \& Maxillofacial Surgery, College of Health Sciences, Usmanu Danfodiyo University/ Usmanu Danfodiyo University Teaching Hospital, Sokoto, Nigeria.

E-mail: droataiwo@yahoo.com, Phone number:+234 8078061517

5. Muhammed Oboirien: MBBS, FWACS, Senior lecturer/Consultant Orthopaedic and Traumatology Surgeon, Orthopaedic and Traumatology Unit, Department of Surgery, Usmanu Danfodiyo University Teaching Hospital, Sokoto, Nigeria.

E-mail: moboirien@yahoo.com , Phone number: +234 8067893799

6. Adejobi Adewale Francis (B.Ch.D), Senior Registrar, Department of Oral \& Maxillofacial Surgery and Oral Pathology, Obafemi Awolowo University Teaching Hospitals Complex, Ile-Ife Osun State, Nigeria. E mail; walerosy@yahoo.com

Phone number +23408148668418

7. Ndubuisi Godwin.T (BDS, MSc), Junior Registrar, Department of Dental \& Maxillofacial Surgery Usmanu Danfodiyo University Teaching Hospital, Sokoto, Nigeria E mail; , Phone number +234 8030920154

8. Abubakar Siddiq (BDS), Junior Registrar, Department of Dental \& Maxillofacial Surgery Usmanu Danfodiyo University Teaching Hospital, Sokoto, Nigeria E mail; elbukarfawa2000@gmail.com, Phone number +234 8069457770

\section{Abstract}

Background: Reconstruction of mandibular defects can be challenging because an acceptable aesthetic and functional outcome must be achieved simultaneously.

Aim: To evaluate the pattern of mandibulectomy and reconstruction materials used in the reconstruction of mandibular defects.

Materials and methods: This was a retrospective study of mandibulectomies with reconstruction in Sokoto, Nigeria between 2012 and 2016. Data such as demographics, type of tumour, type of resection and type of reconstruction materials used were extracted and stored.

Results: Fifty-two cases of mandibulectomies were done comprising 24 males and 28 females (ratio 1:1.2). Age ranged 5-80 years with mean \pm SD (37.8 \pm 15$)$. Most of the cases $30(57.7 \%)$ were on the right. There are $35(67.3 \%)$ benign and $17(32.7 \%)$ malignant cases. Thirty (57.7\%) lateral, $16(30.8 \%)$ condylar, $1(1.9 \%)$ central and $5(9.6 \%)$ combined mandibular defects were seen. Reconstruction plate alone was used in $11(21.2 \%)$ cases, reconstruction plate with rib and tibia grafts in $16(30.8 \%)$ cases, reconstruction plate with Iliac crest and tibia grafts in $15(28.8 \%)$ cases. Graft length ranged from $0-20 \mathrm{~cm}$. There was satisfactory outcome altogether in $32(80.0 \%)$.

Conclusion: This study has shown the types of mandibulectomies and reconstruction materials used in our centre.

Keywords: Grafts, mandibular defects, reconstruction plate.

DOI: https://dx.doi.org/10.4314/ahs.v19i3.53

Cite as: Braimah RO, Ibikunle AA, Abubakar U, Taino AO, Oboirien M, Adejobi FA, Ndubuisi TG, Abubakar S. Mandibular reconstruction with autogenous non-vascularised bone graft. Afri Health Sci. 2019;19(3): 2768-2777. bttps:/ / dx.doi.org/10.4314/abs.v19i3.53

\section{Corresponding author:}

Ramat Oyebunmi Braimah,

Department of Dental and Maxillofacial Surgery,

Usmanu Danfodio University Teaching Hospital,

Sokoto, Nigeria.

Phone number +2348035839900

Email: robdeji@yahoo.com.,

bunmibraimah@gmail.com

\section{Introduction}

The mandible which forms the lower $3^{\text {rd }}$ of the facial skeleton is an important structure for function (mastication, speech and deglutition), esthetics and quality of life $\mathrm{l}^{1,2}$. Mandibular defects may result from trauma, e.g road traffic accidents, gunshot and blast injuries ${ }^{3}$, inflammatory disease e.g. osteomylitis, benign or malignant tumor ablation, complication of radiotherapy e.g osteoradionecrosis and congenital defects.

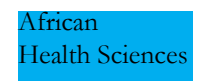

(C) 2019 Braimah et al. Licensee African Health Sciences. This is an Open Access article distributed under the terms of the Creative commons Attribution License (https://creativecommons.org/licenses/BY/4.0), which permits unrestricted use, distribution, and reproduction in any medium, provided the original work is properly cited.

African Health Sciences Vol 19 Issue 3, September, 2019 
Mastication, speech and facial esthetics are often severely compromised without reconstruction of the defects. Reconstruction of these defects remains a challenge because an acceptable aesthetic and functional outcome must be achieved simultaneously. These challenges are further compounded by radiation therapy in case of malignant tumor and further soft tissue loss. Therefore, many options and modalities should be at the surgeons disposal to meet individual challenges. Existing techniques include reconstruction plates/bars with/without pedicled myocuteneous flaps, PBCM (Particulate bone cancellous marrow) graft, free grafts, pedicled osteomyocutaneous flaps and a variety of free vascularised bone flap ${ }^{4,5}$. Due to this complexity in mandibular reconstruction, the technique and principles have evolved over time. Recently, the standard method of mandibular reconstruction is microvascular surgery replacing the previous use of free non-vascularized autogenous bone grafting ${ }^{6,7}$. Because of the various challenges of previous techniques for mandibular reconstruction, new techniques are emerging and have been tested to eliminate need for harvesting bone from donor sites. These new techniques include Transport disc distraction osteogenesis ${ }^{8}$, tissue engineering ${ }^{9,10}$ and modular endoprosthesis ${ }^{11}$.

Several studies have been conducted in other regions of Nigeria on pattern of mandibulectomies and materials of reconstruction ${ }^{2,12,13}$, however, no study has been performed in the extreme NorthWest region of Nigeria, specifically, Sokoto, hence the rationale for this study. The main aim of the current study therefore, was to evaluate the pattern of mandibulectomy and reconstruction materials used in the reconstruction of mandibular defects following tumour ablation in Sokoto, extreme NorthWest region of Nigeria where there is lack of manpower and limited resources. This will allow relevant authority to adequately mobilize resources and manpower to solve this health challenge.

\section{Materials and methods}

This is a retrospective study from Usmanu Danfodiyo University Teaching Hospital (UDUTH), Sokoto, between 2012-2016. UDUTH is the biggest tertiary referral centre in Sokoto state. It served a largely remote rural population of over 6 million people in Sokoto and oth- er neighbouring states of Kebbi, Zamfara, Niger, Katsina and two neighbouring Countries (Benin Republic and Niger Republic) with land mass spanning more than 25.973 square kilometres. In addition, the hospital has a functional linear accelerator radiotherapy machine with Consultants Radio-oncologists and Nuclear Physicists in managing malignant lesions. Data retrieved include gender, age, diagnosis, and extent of mandibular resection, types of reconstruction materials, graft length and outcome of surgery. The modified La-Co-Ce system of classifying mandibular defects proposed by Arotiba et $\mathrm{al}^{14}$ was adopted for this study. This modified La-Co-Ce sstem has classified mandibular defects into; i. Unilateral segmental mandibular defects from sympysis menti to ramus with preservation of the condyle (Uni- Lateral defect; La), ii. Unilateral segmental defects with sacrifice of one condyle (Uni-Condylar defects; Co), iii. Isolated Central defect (mental foramen to mental foramen; CE), iv. Combination Central-Uni-Lateral (CE-La) and Central- Uni-Condylar (CE-Co) defects, v. Combination Central-Bi-lateral (La-CE-La) and Central- Bi-Condylar (Co-CE-Co) defects (Total mandibulectomy). All cases of mandibular resection (both for benign and malignant lesions) and with/without reconstruction with complete records were included in the study, while cases with incomplete records were excluded. Outcome measures include successful reconstruction without failure (both bone graft and reconstruction plate) or tumour recurrence. All patients were monitored for a period of 10 months after which some were lost to follow up.

Ethical approval was obtained from the Ethics and Research committee of Usmanu Danfodiyo University Teaching Hospital with reference number UDUTH/ HREC/2017/591.

Data was analyzed using SPSS for Window version 20.0 (Armonk, NY: IBM Corp). Results were presented as simple frequencies and descriptive statistics. A P value of less than 0.05 was considered significant.

\section{Results}

A total of 52 cases of mandibulectomies were carried out during the study period comprising 24 (46.2\%) males and $28(53.8 \%)$ females with a M:F of 1:1.2. Patients age ranged from 5-80 years with a mean \pm SD (37.8 \pm 15$)$ (Table 1). 
Table 1: Distribution of gender and age group of patients that had mandibullar resection

\begin{tabular}{lccc}
\hline \multicolumn{4}{c}{ Gender } \\
\hline $\begin{array}{l}\text { Age- } \\
\text { group (years) }\end{array}$ & Male (\%) & Female (\%) & Total (\%) \\
\hline $\mathbf{5 - 1 0}$ & $0(0.0)$ & $1(1.9)$ & $1(1.9)$ \\
$\mathbf{1 1 - 2 0}$ & $1(1.9)$ & $0(0.0)$ & $1(1.9)$ \\
$\mathbf{2 1 - 3 0}$ & $13(25.0)$ & $6(11.5)$ & $19(36.5)$ \\
$\mathbf{3 1 - 4 0}$ & $7(13.5)$ & $9(17.3)$ & $16(30.8)$ \\
$\mathbf{4 1 - 5 0}$ & $3(5.8)$ & $3(5.8)$ & $6(11.6)$ \\
$\mathbf{5 1 - 6 0}$ & $0(0.0)$ & $5(9.6)$ & $5(9.6)$ \\
$\mathbf{6 1 - 7 0}$ & $0(0.0)$ & $2(3.8)$ & $2(3.8)$ \\
$\mathbf{7 1 - 8 0}$ & $0(0.0)$ & $2(3.8)$ & $2(3.8)$ \\
Total & $24(46.2)$ & $28(53.8)$ & $52(100.0)$ \\
\hline $2=13.602$, df $=7, \mathrm{p}=0.059$ & & &
\end{tabular}

Thirty $(57.7 \%)$ cases involved the right side of the mandible, while 17 (32.7\%) involved the left side and 5 (9.6\%) cases are bilateral. Most of the reasons for mandibulectomy were due to benign lesions $35(67.3 \%)$ with ameloblastoma accounting for most of them $28(80 \%)$. Only $17(32.7 \%)$ cases were malignant with majority been osteosarcoma 7 (41.2\%) (Table 2). With the adoption of the simplified La-Co-Ce system, 30 (57.7\%) involved the lateral, $1(1.9 \%)$ the central, while $16(30.8 \%)$ cases involved the condylar area and $5(9.6 \%)$ were combined.
No statistical significant difference was observed when the diagnosis was compared with the extent of the lesion (Table 2).

No reconstruction was carried out in $10(19.2 \%)$ patients, while only $11(21.2 \%)$ cases had their jaws reconstructed with only reconstruction plate (Figure 1). Nine (17.3\%) patients had their mandible reconstructed with titanium reconstruction plate and iliac bone graft only (Figure 2) while in 6 (11.5) cases iliac bone graft was combined with cancellous bone graft from the proximal tibia (Table 3).

Table 2: Distribution of extent of mandibulectomy (Modified La-Co-Ce System) and diagnosis of the pathology

\begin{tabular}{|c|c|c|c|c|c|}
\hline \multirow[b]{2}{*}{ Diagnosis } & \multicolumn{4}{|c|}{ Extent } & \multirow[b]{2}{*}{$\begin{array}{l}\text { Total } \\
(\%)\end{array}$} \\
\hline & $\begin{array}{c}\text { Lateral } \\
(\%)\end{array}$ & Condylar (\%) & Central $(\%)$ & Combined (\%) & \\
\hline \multicolumn{6}{|l|}{ Benign } \\
\hline Ameloblastoma & $15(28.8)$ & $11(21.2)$ & $0(0.0)$ & $2(3.8)$ & $28(53.8)$ \\
\hline Fibrous dysplasia & $2(3.8)$ & $0(0.0)$ & $0(0.0)$ & $0(0.0)$ & $2(3.8)$ \\
\hline Ossifying fibroma & $1(1.9)$ & $0(0.0)$ & $0(0.0)$ & $1(1.9)$ & $2(3.8)$ \\
\hline $\begin{array}{l}\text { Central giant cell } \\
\text { granuloma }\end{array}$ & $1(1.9)$ & $0(0.0)$ & $0(0.0)$ & $0(0.0)$ & $1(1.9)$ \\
\hline $\begin{array}{l}\text { Keratocystic } \\
\text { odontogenic tumour }\end{array}$ & $1(1.9)$ & $0(0.0)$ & $0(0.0)$ & $0(0.0)$ & $1(1.9)$ \\
\hline $\begin{array}{l}\text { Odontogenic } \\
\text { myxoma }\end{array}$ & $1(1.9)$ & $0(0.0)$ & $0(0.0)$ & $0(0.0)$ & $1(1.9)$ \\
\hline \multicolumn{6}{|l|}{ MALIGNANT } \\
\hline Squamous & $2(3.8)$ & $1(1.9)$ & $1(1.9)$ & $1(1.9)$ & $5(9.6)$ \\
\hline carcinoma & $7(13.5)$ & $0(0.0)$ & $0(0.0)$ & $0(0.0)$ & $7(13.5)$ \\
\hline Osteosarcoma & $0(0.0)$ & $1(1.9)$ & $0(0.0)$ & $1(1.9)$ & $2(3.8)$ \\
\hline Fibrosarcoma & $0(0.0)$ & $2(3.8)$ & $0(0.0)$ & $0(0.0)$ & $2(3.8)$ \\
\hline Rhabdomyosarcoma & $0(0.0)$ & $1(1.9)$ & $0(0.0)$ & $0(0.0)$ & $1(1.9)$ \\
\hline $\begin{array}{l}\text { Thyroid follicular } \\
\text { carcinoma }\end{array}$ & & & & & \\
\hline Total & $30(57.7)$ & $16(30.8)$ & $1(1.9)$ & $5(9.6)$ & $52(100.0)$ \\
\hline
\end{tabular}




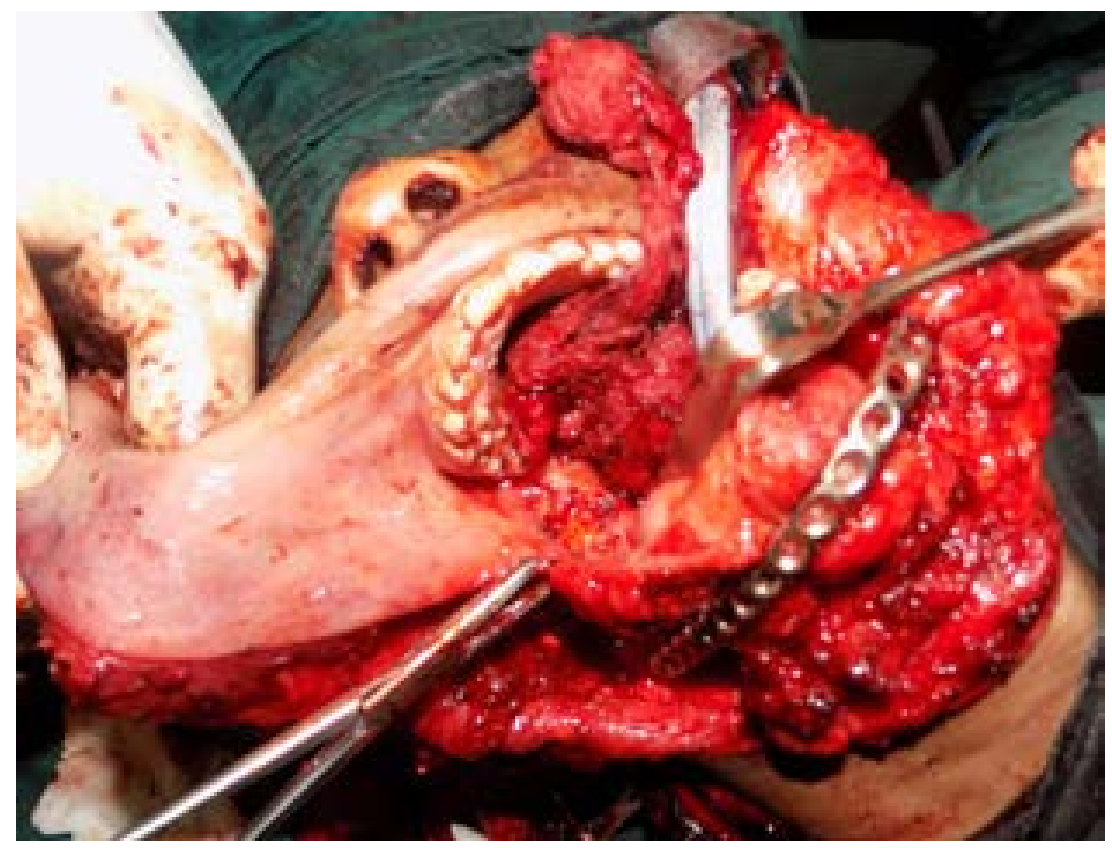

Figure 1: Clinical photograph of mandibular reconstruction with reconstruction plate only

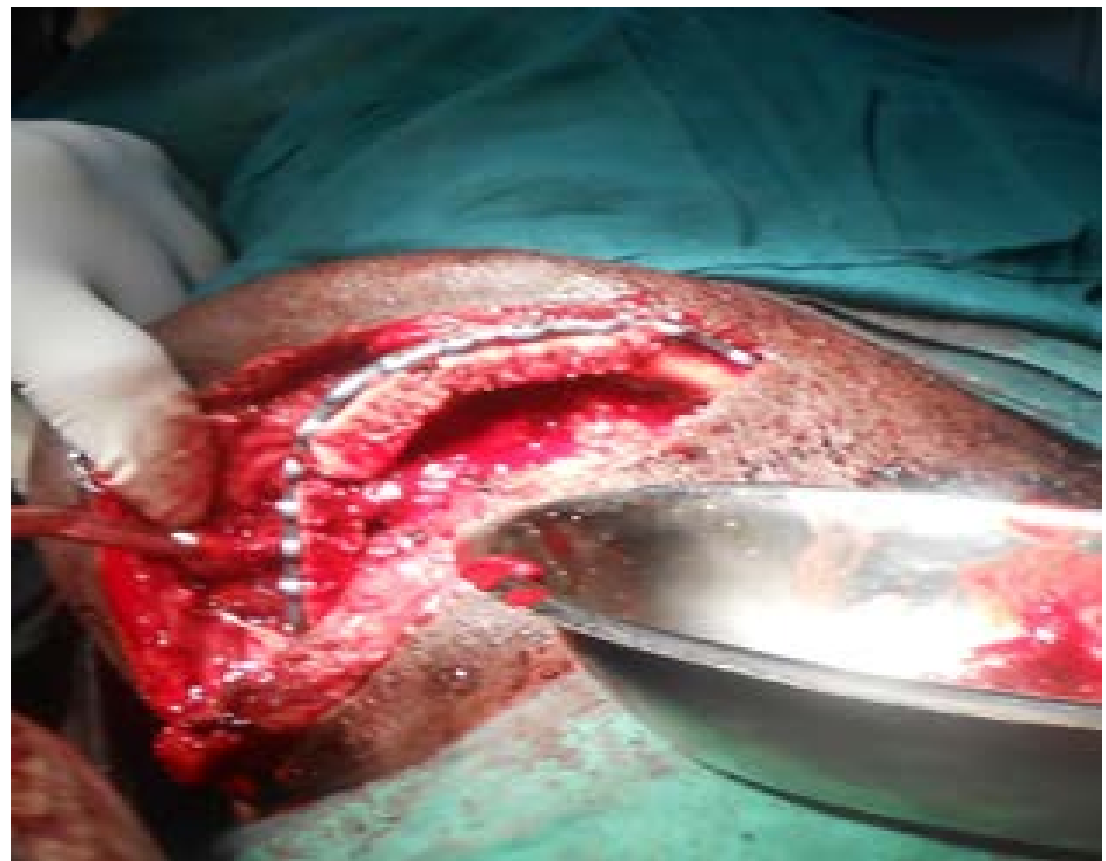

Figure 2: Clinical photograph of mandible reconstructed with titanium reconstruction plate and iliac bone graft only 
Table 3: Distribution of types and materials for reconstruction

\begin{tabular}{lll}
\hline & Frequency & $\mathbf{\%}$ \\
\hline No reconstruction & 10 & 19.2 \\
Reconstruction plate alone & 11 & 21.2 \\
Reconstruction plate + iliac crest graft only & 9 & 17.3 \\
Reconstruction plate + iliac crest + tibia graft & 6 & 11.5 \\
Reconstruction plate + Rib graft only & 11 & 21.2 \\
Reconstruction plate + Rib graft + tibia graft & 4 & 7.7 \\
Reconstruction plate + Rib graft + condyle & 1 & 1.9 \\
Total & 52 & 100.0 \\
\hline
\end{tabular}

Only $1(1.9 \%)$ patient had the mandible reconstructed (Figure 4) and $4(7.7 \%)$ had their mandibles reconstructwith a titanium condyle and rib graft (Figure 3). Eleven ed with rib graft and cancellous bone graft from the prox$(21.2 \%)$ patients were reconstructed with rib graft alone imal tibia (Table 3 ).

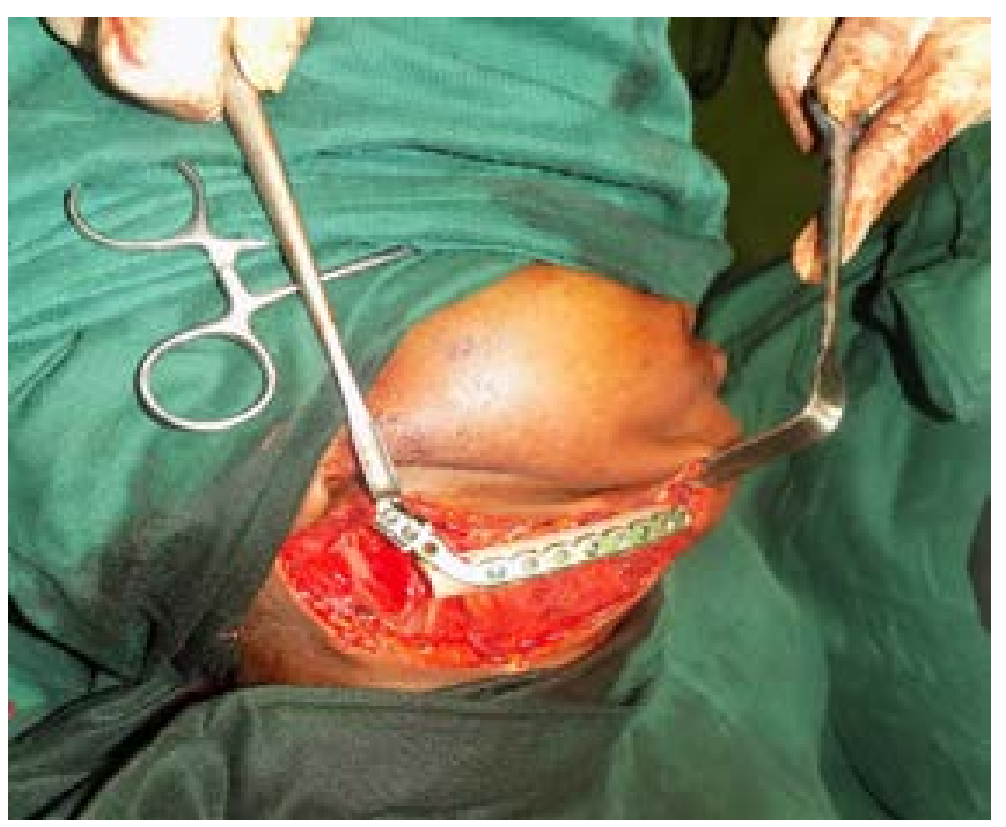

Figure 3: Clinical photograph of mandible reconstructed with a titanium condyle and rib graft

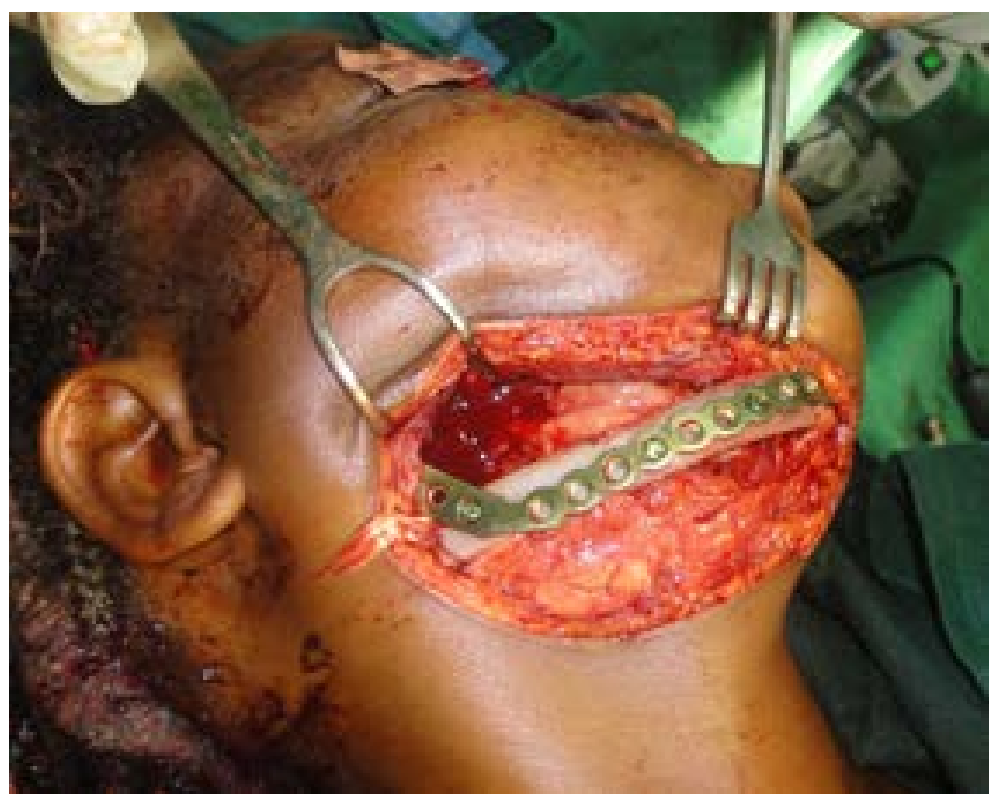

Figure 4: Clinical photograph of mandible reconstructed with rib graft alone 
Graft length ranged from $0-20 \mathrm{~cm}$. Out of 31 cases of grafts used as immediate reconstruction in our study 6 $(19.4 \%)$ grafts failed (total failure in $3(9.7 \%)$ iliac bone grafts and partial failure in $3(9.7 \%)$ rib grafts) while 25
$(80.6 \%)$ had successful take. Reconstruction plate extrusion (Figure 5) was observed in $2(4.8 \%)$ patients $(n=42)$. There was satisfactory outcome altogether in $32(80.0 \%)$ patients $(\mathrm{n}=40)$, while outcome in $12(33.3 \%)$ patients was unknown due to loss in follow-up (Table 4).

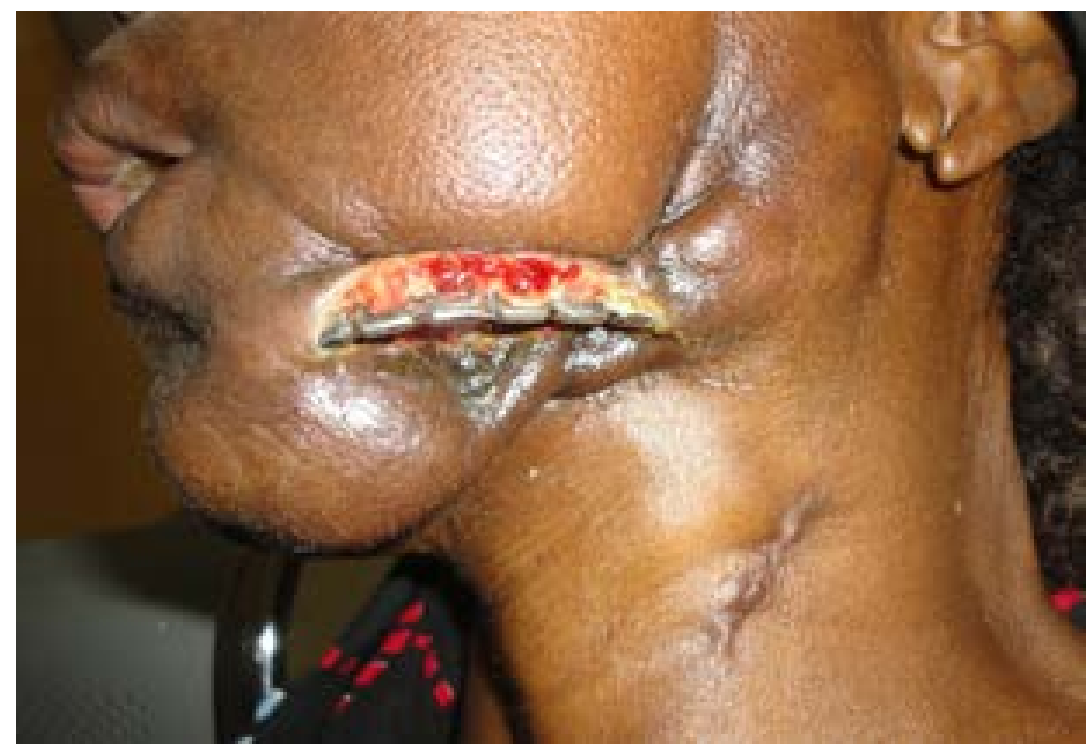

Figure 5: Reconstruction plate extrusion as one of the complications

Table 4: Distribution of graft length and outcome of surgery

\begin{tabular}{lccccc}
\hline \multicolumn{7}{c}{$\begin{array}{c}\text { Outcome } \\
\text { length } \\
(\mathbf{c m})\end{array}$} & $\begin{array}{c}\text { Satisfactory } \\
\text { Outcome } \\
(\%)\end{array}$ & $\begin{array}{c}\text { Failed } \\
\text { graft } \\
\mathbf{( \% )}\end{array}$ & $\begin{array}{c}\text { Recon } \\
\text { Plate } \\
\text { extrusion } \\
(\mathbf{\%})\end{array}$ & $\begin{array}{c}\text { Not } \\
\text { known }(\%)\end{array}$ & $\begin{array}{c}\text { Total } \\
(\%)\end{array}$ \\
\hline $\mathbf{0}$ & $8(15.4)$ & $0(0.0)$ & $2(3.8)$ & $11(21.2)$ & $21(40.4)$ \\
$\mathbf{4}$ & $1(1.9)$ & $0(0.0)$ & $0(0.0)$ & $0(0.0)$ & $1(1.9)$ \\
\hline $\mathbf{7}$ & $3(5.8)$ & $0(0.0)$ & $0(0.0)$ & $1(1.9)$ & $4(7.7)$ \\
$\mathbf{8}$ & $5(9.6)$ & $1(1.9)$ & $0(0.0)$ & $0(0.0)$ & $6(11.5)$ \\
$\mathbf{9}$ & $4(7.7)$ & $1(1.9)$ & $0(0.0)$ & $0(0.0)$ & $5(9.6)$ \\
$\mathbf{1 0}$ & $7(13.5)$ & $2(3.8)$ & $0(0.0)$ & $0(0.0)$ & $9(17.3)$ \\
$\mathbf{1 1}$ & $2(3.8)$ & $1(1.9)$ & $0(0.0)$ & $0(0.0)$ & $3(5.8)$ \\
$\mathbf{1 8}$ & $2(3.8)$ & $0(0.0)$ & $0(0.0)$ & $0(0.0)$ & $2(3.8)$ \\
$\mathbf{2 0}$ & $0(0.0)$ & $1(1.9)$ & $0(0.0)$ & $0(0.0)$ & $1(1.9)$ \\
Total & $32(61.5)$ & $6(11.5)$ & $2(3.8)$ & $12(23.1)$ & $52(100.0)$ \\
\hline
\end{tabular}

$\chi 2=37.138, \mathrm{df}=24, \mathrm{p}=0.042$

\section{Discussion}

Mandibular reconstruction principles and techniques have evolved significantly over the last century. Despite the enormous progress made over the last 40 years, ideal solution in terms of anatomical reconstruction with enough height of mandible and muscle attachment to allow for function (mastication, speech and deglutition), aesthetics and good quality of life has not yet been achieved $^{15}$.
Overall female preponderance $(53.8 \%)$ was observed in our study which is in support of other reported studies $^{12,16,17}$. Good health seeking behaviour of females may have contributed to these findings. Okojie et $\mathrm{al}^{13}$ on the contrary have reported a male preponderance from the southwest region of Nigeria. Age range of patients requiring mandibulectomy in our series was 5-80 years. Similar age range have been reported by Ndukwe et a ${ }^{12}$ (13-73 years) and Olojede et $\mathrm{al}^{17}$ (5-80years) in SouthWest 
of Nigeria. However, Okojie et $\mathrm{al}^{13}$ from SouthWest Nigeria has reported a much lower age group (12-45 years) in their series. This lower age range has been reported by Anjum et $\mathrm{al}^{16}$.

Mandibular defects reconstruction following tumour resection in the paediatric age group is a particular challenge because of the growing child. This is important both at the donor sites for autogenous bone grafts harvesting and the complex mandibulo-facial region as a result of growth and development ${ }^{18}$. The literature has established that alloplastic materials should not be utilised in mandibular reconstruction during the active growth period in the paediatric age groups ${ }^{19}$. Various donor sites (rib graft, free and revascularized iliac crest, revascularized fibula) have been utilised in mandibular reconstruction, however, choice depends on age of patient at the time of reconstruction and bone volume required ${ }^{20}$. The ribs have been favoured for mandibular reconstruction in the paediatric age group despite its limited bone volume because of the growth potential of the costochondrial $\mathrm{graft}^{20}$. None of the paediatric patients in our series had reconstruction of the mandibular defects because ablated tumours weremalignant. Although, studies have reported spontaneous bone formation in the paediatric age group if the periosteum was intact ${ }^{21}$, this was not achieved in our series because of the aggressive resection.

Although, mandibular defects results from different aetiologies, studies have shown that tumour ablation (both benign and malignant) accounted for most of the reasons for mandibular defects requiring reconstruction ${ }^{2,22-24}$. In our study, all the cases of mandibular defects that needed reconstruction were due to tumour ablation of both benign $35(67.3 \%)$ and malignant ${ }^{17}(32.7 \%)$ cases. All cases in our series that needed reconstruction with bone graft had immediate reconstruction after tumour ablation. This was because cost of secondary surgery is almost out of reach in resource scarce countries where most of health care financing is made out of pocket by patients. Health care spending in Nigeria is segmented into private and public spending. Public health expenditures in Nigeria account for just $20-30 \%$ of total health expenditures, private expenditures accounts for $70-80 \%$ of total health expenditure. The dominant private expenditure is through out-of-pocket, which accounts for more than $90 \%$ of private health expenditures ${ }^{25,26}$.

Out of the $35(67.3 \%)$ benign tumour cases, ameloblastoma accounted for $28(80 \%)$ which is in tandem with the study by Okojie et $\mathrm{al}^{13}$ in the SouthWest region of Nigeria. Ameloblastoma is regarded as the commonest odontogenic tumour affecting the mandible in black Africans ${ }^{17,27}$ and has been said to be more common among Africans than Caucasians ${ }^{28}$. Osteosarcoma was the commonest malignant tumour in our series while ameloblastic carcinoma was the commonest in the study by Okojie et $\mathrm{al}^{13}$.

None of our malignant cases were reconstructed with bone grafts; they were either given reconstruction plate only or left without any reconstruction. The main reason was to ensure tumour free margins before graft placement as a secondary procedure. Unfortunately, none of these patients presented for secondary reconstruction as most were lost to follow-up. Studies have shown that reconstructing mandibular defects as a result of malignant tumour ablation often leads to graft failure due to tumour recurrence and/or effects of radiotherapy/chemothera$\mathrm{py}^{29,30}$.

The use of reconstruction plate alone as temporary measure in mandibular reconstruction is influenced by two major concerns: the potential for tumour recurrence and postsurgery radiation and/chemotherapy. Other concerns include amount of time reconstruction will add to the length of surgery and mobidity associated with complex reconstructive procedures especially in medically compromised patients. This temporary measure has been known to offer significant advantages including: support for remaining bone and soft tissue pending time for definitive reconstruction using graft of flap. In addition, it maintains facial contour and lessens post-surgery airway and swallowing problems leading to improved patient's quality of life $\mathrm{l}^{31}$.

The reconstructive oral and maxillofacial surgeon still finds mandibular reconstruction very challenging because of the complex anatomy of the mandible. It is a U- shaped bone with articulations to the temporal bone of the skull via the temporo-mandibular joint ${ }^{32}$. Additionally, the mandible has several curves that makes it challenging to reproduce ${ }^{33,34}$. In order to influence the outcome of the mandibular reconstruction, several classifications have been suggested to catalogue this complex bony structure ${ }^{35,36}$. Gemert et $\mathrm{al}^{37}$ have classified mandibular defects into: true lateral (condyle, ramus, body, ramus body), hemisymphyseal (Sh) and complete symphyseal, while Jewer et $\mathrm{al}^{38}$ classified it into Hemi-Man- 
dibular-Central- Lateral (H-C-L) segmental mandibular defects. The shortcomings of these two classification systems is that they did not take into cognisance the extent and anatomic locations of these defects though they look into the complexity of the reconstruction ${ }^{14}$. Based on these shortcomings, Arotiba et $\mathrm{al}^{14}$ proposed the LaCo-Ce system (as described in the methodology). This current study adopted the la-Co-Ce system because of its simplicity.

All cases reconstructed with non-vascularised graft in our series were fixed with reconstruction plate (Figure 4). Rigidity of graft during the healing phase of the graft have been reported to aid take of the graft by preventing micro-movement and possible infection of the $\mathrm{graft}^{12,37}$. Non rigid fixation of grafts has resulted in graft failure with subsequent graft removal. Another important factor in graft take is the length of the graft. Studies have reported graft failure in long span defects measuring $12 \mathrm{~cm}$ and have recommended that such defects should only be reconstructed with vascularised grafts ${ }^{22,24,39}$. Our series have recorded up to $20 \mathrm{~cm}$ graft length, while most of the grafts are well over $7 \mathrm{~cm}$ in length. Despite this length, most of our graft had complete take (25 $(80.6 \%), n=31)$. We opined that high aseptic technique and rigid graft immobilization could be responsible. Ndukwe et $\mathrm{al}^{12}$ have also highlighted mandibulo-maxillary fixation (MMF) for 5 weeks after surgery as a possible reason for graft take. None of our patients were placed in MMF after surgery as early minimal jaw movement was encouraged. We then speculated that probably, graft fixation using reconstruction plate may have contributed more to graft take rather than MMF.

Iliac bone graft have been known to give adequate bulk for structural stability, implant placement for rehabilitation and also provide good osteoblastic cells mainly for osteogenesis because of rich cancellous bone ${ }^{40}$. However, they have been associated with high rate of resorption ${ }^{12}$. Rib grafts on the other hand have less bulk because of scanty cancellous bone and more cortical bone mainly for osteoconduction ${ }^{41}$. Form our study, 16 (51.6\%) cases were rib grafts while $15(48.4 \%)$ cases were iliac bone. Overall, $10(32.3 \%)$ patients developed infection in our series which correlates with reported cases of $20-36 \%$ infection rates in the literature $24,37,42$. However, infection rate leading to graft failure was $19.6 \%$ (6 cases) which is in tandem with those reported in the literature ${ }^{13,22,24}$ but contrasted the study by Ndukwe et $\mathrm{al}^{12}$ where they re- ported lower failure rate of $12 \%$. Extension of antibiotic regimen for 10 days was the reason given to this low rate. Several factors have been identified that increase the probability of postoperative infections, such include; immediate reconstruction, reconstruction through intraoral route and reconstruction in previously irradiated site ${ }^{24}$, 37,42 . All the cases for graft placement had immediate reconstruction and tumour ablation was through both intraoral and extraoral approaches. Despite these downbeat factors, infection rate was still at its minimum. We also observed from our series that out of the $6(19.6 \%)$ cases of graft failure, $3(50 \%)$ cases of the iliac graft had total graft failure necessitating total graft removal, while only $1(33.3 \%)$ case in the rib graft had total failure with 2 $(66.6 \%)$ having partial failure. We then opined that probably,because of the high cancellous component of iliac graft, they may be prone to infection unlike the rib that is more of cortical bone. Dankor et $\mathrm{al}^{43}$ in their series have concluded that soaking the graft in $300 \mathrm{mg}$ Clindamycin $/ 500 \mathrm{ml}$ normal saline have contributed to graft survival, however, randomised control trial is necessary to verified this claim.

This study has been able to highlight the different types of reconstruction techniques with their associated complications in resource limited environment. Major limitation in this series is the retrospective nature of the study where some data had been lost. Also, long term follow-up of these patients was extremely tasking as quite a number were lost to follow up.

\section{Conclusion}

This study has shown the types of mandibulectomies and reconstruction materials used in our centre. Although there are many options for mandibular reconstruction, non vascularised bone grafts still remain a practicable option for the reconstruction of mandibular defects secondary to benign tumour ablation especially in sub-Saharan Africa where resources are limited. Improved techniques such as careful planning by classifying the surgical defects and graft fixation using reconstruction plate and screws can improve graft take despite long span reconstruction.

\section{Conflict of interest}

None declared.

\section{References}

1. Mehta RP, Deschler DG. Mandibular reconstruction in 2004: an analysis of different techniques. 2004;12:288- 
93. Curr Opin Otolaryngol Head Neck Surg. 2004;12:288-93. 2. Obiechina AE, Ogunlade SO, Fasola AO, Arotiba JT. Mandibular segmental reconstruction with iliac crest. West Afr J Med. 2003;22(1):46-49.

3. Ahmed FT, Aljeuary MT. The Strategy of Delayed Reconstruction of the Mandible in War Injuries. Journal of Craniofacial Surgery. 2017;28(2):826-30.

4. Cullane PJ, Holmes H. Mandibular reconstruction- New concepts. Arch Otolryngol Head Neck Surg. 1976;112:71419.

5. Urken ML. Composite free flap in oromandibular reconstruction. Arch Otolryngol Head Neck Surg. 1991;117:724-32.

6. Strauch B, Bloomberg AE, Lewin ML. An experimental approach to mandibular replacement: Island vascular composite rib grafts. Br J Plast Surg. 1971;24:334-41. PubMed

7. Conley J. Use of composite flaps containing bone for major repairs in the head and neck. Plast Reconstr Surg. 1972;49:522-26. PubMed

8. Herford AS. Use of a plate-guided distraction device for transport distraction osteogenesis of the mandible. $J$ Oral Maxillofac Surg. 2004;62:412-20. PubMed

9. Warnke PH, Springer IN, Wiltfang J, et al. Growth and transplantation of a custom vascularised bone graft in a man. Lancet. 2004;364:766-70. PubMed

10. Warnke PH, Wiltfang J, Springer I, et al. Man as a living bioreactor: fate of an exogeneously prepared customized tissue-engineered mandible. Biomaterials. 2006;27:316367. PubMed

11. Tideman H, Lee S. The TL endoprosthesis for mandibular reconstruction- a metallic yet biological approach. Asian J Oral Maxillofac. 2006;18:5.

12. Ndukwe KC, Aregbesola SB, Ikem IC, et al. Reconstruction of Mandibular Defects Using Nonvascularized Autogenous Bone Graft in Nigerians. Nigerian Journal of Surgery. 2014;20(2):87-91.

13. Okojie VN, Obimakinde OS, Arotiba JT, et al. Mandibular defect reconstruction with nonvascularized iliac crest bone graft. Niger J Clin Pract. 2012;15:224-27. PubMed

14. Arotiba GT, Arotiba JT, Bamgbose BO, Gbotolorun MO, Olasoji HO. Mandibular reconstruction a new defect classification system. Nigerian Dent J. 2009.

15. Alfotawi R, Ayoub A. Reconstruction of maxillofacial bone defects: Contemporary methods and future techniques. American Journal of Advances in Medical Science. 2014;2(1):18-27.
16. Aajum S, Khan NA, Ahmad M. Treatment outcomes of reconstruction with iliac bone graft and rib graft in patients with mandibular defects. Pakistan Oral \& Dental Journal.2013;33(3):423-25. PubMed

17. Olojede ACO, Adamson OO, Gbotolorun OM, et al. Mandibular Reconstruction: a Clinical Evaluation of the La-Co-CE Segmental Defect Classification System. JSM Dent Surg. 2017;2(1):1012-18. PubMed

18. Genden EM, Buchbinder D, Chaplin JM, et al. Reconstruction of Paediatric Maxilla and Mandible. Arch Otolryngol Head Neck Surg. 2000;126:293-300.

19. Girotto JA, Gruss J. Primary post-traumatic mandibular reconstruction in infancy: a 10-year follow-up. J Craniofac Surg. 2004;15:255-59 PubMed .

20. Eckardt AM, Barth EL, Berten J, Gellrich NS. Pediatric Mandibular Resection and Reconstruction: LongTerm Results with Autogenous Rib Grafts. Craniomaxillofac Trauma and Reconstr. 2010;3(1):25-32.

21. Boyne PJ. The restoration of resected mandibles in children without the use of bone grafts. Head Neck Surg. 1983;6:631-26. PubMed

22. Pogrel MA, Podlesh S, Anthony JP, Alexander J. A comparison of vascularized and nonvascularized bone grafts for reconstruction of mandibular continuity defects. J Oral Maxillofac Surg. 1997;55:1200-06.

23. Adekeye EO. Reconstruction of mandibular defects by autogenous bone grafts: A review of 37 cases. J Oral Surg. 1978;36:125-28. PubMed

24. Arotiba JT, Obimakinde OS, Ogunlade SO, et al. An audit of mandibular defect reconstruction methods in a Nigerian Tertiary Hospital. Niger Postgrad Med J. 2011;18:172-76.

25. Soyibo A. National Health Accounts of Nigeria, 1998-2002. Final Report, 2005 submitted to the World Health Organization. 2004.

26. Soyibo A, Olaniyan O, Lawanson A. A Situational Analysis of the Nigerian Health Sector; Report Submitted to Management Education Research Consortium, Washington DC. 2009.

27. Adebayo ET, Ajike SO, Adekeye EO. A review of 318 odontogenic tumors in Kaduna, Nigeria. J Oral Maxillofac Surg. 2005;63:811-19.

28. Shear M, Singh S. Age-standardized incidence rates of ameloblastoma and dentigerous cyst on the Witwatersrand, South Africa. Community Dent Oral Epidemiol 1978;6:195-99.

29. O’Brien CJ, Archer DJ, Breach NM, Shaw HJ. Reconstruction of the mandible with autogenous bone follow- 
ing treatment for squamous cell carcinoma. Aust N Z J Surg. 1986;56:707-15. PubMed

30. Adamo AR, Szal RL. Timing, results and complications of mandibular reconstructive surgery: report of 32 cases. J Oral Surg. 1979;37:755-63. PubMed

31. Kumar BP, Venkatesh V, Kumar KAJ, Yadav BY, Mohan SR. Mandibular Reconstruction: Overview. J. Maxillofac. Oral Surg. 2016;15(4):425-41. PubMed

32. Arotiba GT. The Society, Ivory Tower, Mouth, Jaw and Face Surgery in a developing economy. University of Lagos Press (Inaugural Lecture $4^{\text {th }}$ January, 2012): 59-63. 2012.

33. Hull W, Miloro M, Kolokythas A. Is immediate reconstruction of the mandible with nonvascularized bone graft following resection of benign pathology a viable treatment option? J Oral Maxillofac Surg 2015;73:541-49.

34. Sajid MA, Warraich RA, Abid H, et al. Reconstruction of mandibular defects with autogenous bone grafts:a review of 30 cases. J Ayub Med Coll Abbottabad. 2011;23:8285.

35. Marx RE. Mandibular reconstruction. J Oral Maxillofac Surg. 1993;51:466-79.

36. Gurtner GC, Evans GR. Advances in head and neck reconstruction. Plast Reconstr Surg. 2000;106:672-82. PubMed .
37. van Gemert JT, van Es RJ, van Cann EM, Koole R. Nonvascularized bone grafts for segmental reconstruction of the mandible - a reappraisal. J Oral Maxillofac Surg. 2009;67:1446-52.

38. Jewer DD, Boyd JB, Manktelow RT, et al. Orofacial and mandibular reconstruction with the iliac crest free flap: a review of 60 cases and a new method of classification. Plast Reconstr Surg. 1989;84:391-403. PubMed

39. Bak M, Jacobson AS, Buchbinder D, Urken ML. Contemporary reconstruction of the mandible. Oral Oncol. 2010;46:71-76. PubMed .

40. Goh BT, Lee S, Tideman H, Stoelinga PJ. Mandibular reconstruction in adults: A review. Int J Oral Maxillofac Surg. 2008;37:597-605.

41. Khadka A, Hu J. Autogenous grafts for condylar reconstruction in treatment of TMJ ankylosis: Current concepts and considerations for the future. Int J Oral Maxillofac Surg. 2012;41:94-102.

42. August M, Tompach P, Chang Y, Kaban L. Factors influencing the long term outcome of mandibular reconstruction. J Oral Maxillofac Surg. 2000;58:731-37. PubMed 43. Donkor P, Bankas DO, Boakye G, Ansah S, Acheampong $\mathrm{AO}$. The use of free autogenous rib grafts in maxillofacial reconstruction. Ghana Medical Journal. 2006;40(4):127-31. 